\section{DURKHEIM Y WEBER: SOBRE LOS ANÁLISIS SOCIOLÓGICOS Y LOS ANÁLISIS HISTÓRICOS \\ RICARDO SIDICARO}

Ricardo Sidicaro es Investigador del CONICET con sede en el Instituto de Investigaciones "Gino Germani», de la Universidad de Buenos Aires, y Profesor de esa Universidad y de la Universidad Nacional del Litoral.

\section{Resumen}

Émile Durkheim y Max Weber opinaban que el antagonismo entre los análisis sociológicos y los análisis históricos no existía. Sin embargo los dos fundadores de la Sociología fueron muy críticos de los historiadores en los aspectos conceptuales y epistemológicos. Los paradigmas conceptuales propuestos por Durkheim y Weber elaborados a partir de comparaciones históricas ofrecieron importantes conocimientos para formular nuevas hipótesis e investigaciones. Para Weber, la Sociología y la Historia eran ciencias empíricas de la acción cuyas investigaciones debían proporcionar conocimientos contrarios a las visiones del sentido común. Según el autor, el tema de este artículo es relevante para el caso argentino, en el que las crisis políticas y sociales influyeron negativamente en muchos estudios sociológicos e históricos del siglo XX cuyos argumentos y conclusiones no se diferenciaron de las ilusiones del sentido común y tendieron a identificarse con los valores de los actores.
Dirección laboral: Pte. José E. Uriburu 950, $6^{\circ}$ piso, Ciudad Autónoma de Buenos Aires, CP 1000, Argentina.

\section{Summary}

Émile Durkheim and Max Weber believed that the antagonism between sociological analysis and historical analysis does not exist. However, the two founders of sociology were very critical of historians in the conceptual and epistemological aspects. The conceptual paradigms proposed by Durkheim and Weber made from historical comparisons provided important knowledge to formulate new hypotheses and research. For Weber, Sociology and History were empirical sciences of action whose research should provide knowledge contrary to the views of common sense. According to the author, the subject of this article is relevant to the Argentine case, in which the political and social crises adversely affected many sociological and historical studies of the twentieth century whose arguments and conclusions did not differ from the illusions of common sense and tended to identify with the values of the actors. 